\title{
Different phenotypic and molecular mechanisms associated with multidrug resistance in Gram-negative clinical isolates from Egypt
}

\section{Omneya M Helmy \\ Mona T Kashef}

Department of Microbiology and Immunology, Faculty of Pharmacy, Cairo University, Cairo, Egypt
Correspondence: Omneya M Helmy Department of Microbiology and Immunology, Faculty of Pharmacy, Cairo University, Kasr el-Aini Street, Cairo II562, Egypt

Tel +20225353100

Email omnia.helmy@pharma.cu.edu.eg
This article was published in the following Dove Press journal: Infection and Drug Resistance

\begin{abstract}
Objectives: We set out to investigate the prevalence, different mechanisms, and clonal relatedness of multidrug resistance (MDR) among third-generation cephalosporin-resistant Gramnegative clinical isolates from Egypt.
\end{abstract}

Materials and methods: A total of 118 third-generation cephalosporin-resistant Gramnegative clinical isolates were included in this study. Their antimicrobial susceptibility pattern was determined using Kirby-Bauer disk diffusion method. Efflux pump-mediated resistance was tested by the efflux-pump inhibitor-based microplate assay using chlorpromazine. Detection of different aminoglycoside-, $\beta$-lactam-, and quinolone-resistance genes was done using polymerase chain reaction. The genetic diversity of MDR isolates was investigated using random amplification of polymorphic DNA.

Results: Most of the tested isolates exhibited MDR phenotypes (84.75\%). The occurrence of efflux pump-mediated resistance in the different MDR species tested was 40\%-66\%. Acinetobacter baumannii isolates showed resistance to most of the tested antibiotics, including imipenem. The $b l a_{\text {OXA-23-like }}$ gene was detected in $69 \%$ of the MDR A. baumannii isolates. The MDR phenotype was detected in $65 \%$ of Pseudomonas aeruginosa isolates, of which only $23 \%$ exhibited efflux pump-mediated resistance. On the contrary, efflux-mediated resistance to piperacillin and gentamicin was recorded in $47.5 \%$ of piperacillin-resistant and $25 \%$ of gentamicin-resistant MDR Enterobacteriaceae. Moreover, the plasmid-mediated quinolone-resistance genes ( $a a c\left(6^{\prime}\right)-I b-c r$, $q n r \mathrm{~B}$, and $q n r \mathrm{~S}$ ) were detected in $57.6 \%$ and $83.33 \%$ of quinolone-resistant MDR Escherichia coli and Klebsiella pneumoniae isolates, respectively. The $\beta$-lactamase-resistance gene bla $a_{\mathrm{SHV}-31}$ was detected for the first time in one MDR K. pneumoniae isolate from an endotracheal tube specimen in Egypt, accompanied by $b l a_{\text {TЕM-1 }}, b l a_{\text {СТХ-М-15 }}, b l a_{\text {СТХ-M-14 }}, a a c\left(6^{\prime}\right)-I b-c r, q n r \mathrm{~S}$, and multidrug efflux-mediated resistance.

Conclusion: MDR phenotypes are predominant among third-generation cephalosporin-resistant Gram-negative bacteria in Egypt and mediated by different mechanisms, with an increased role of efflux pumps in Enterobacteriaceae.

Keywords: multidrug resistance, efflux pump, Egypt, Gram-negative bacilli, RAPD typing

\section{Introduction}

Effective treatment of infections is compromised worldwide by the emergence of multidrug resistance (MDR). According to the European Centre for Disease Prevention and Control, MDR is defined as unsusceptibility to at least one agent in three or more of the specified antimicrobial categories used in treatment. ${ }^{1}$

MDR Gram-negative bacteria (MDRGNB) have become a major public health threat, as there are fewer or even sometimes no effective antimicrobial agents available 
for infections caused by these bacteria. ${ }^{2}$ MDR organisms, such as MDR carbapenemase-producing Klebsiella pneumoniae, and Acinetobacter spp., can be resistant to all currently available antimicrobial agents. Sometimes, they may remain susceptible only to older, potentially more toxic agents, such as polymyxins, leaving limited and suboptimal options for treatment. ${ }^{3}$ The problem of increasing antimicrobial resistance is even more threatening when considering the very limited number of new antimicrobial agents in development. ${ }^{4}$

Several biochemical mechanisms can account for the antimicrobial resistance in GNB. These mechanisms include the enzymatic degradation of antibacterial agents, as in case of $\beta$-lactam resistance due to $\beta$-lactamases or modification of the antimicrobial agent by modifying enzymes, as in the case of aminoglycosides. It may also result from the alteration of antimicrobial targets in such organisms, as the in case of topoisomerase IV gene mutations that mediate resistance to fluoroquinolones. Moreover, changes in bacterial membrane permeability to antibiotics caused by mutations resulting in the loss of outer-membrane porin or overexpression of an efflux pump can lead to resistance to many effective antimicrobials. Efflux pumps, which expel multiple kinds of antibiotics, are now recognized as major contributors to MDR in bacteria: they can pump out most of the antibiotics in use. ${ }^{5}$

MDR has been reported to be highly prevalent among different clinical isolates in Egyptian patients; ${ }^{6,7}$ however, few studies have examined the underlying resistance mechanisms. $^{7}$ Third-generation cephalosporins are among the most commonly used antibiotics in Egypt. ${ }^{8}$ Therefore, resistance to third-generation cephalosporin will present a major problem in infection control, especially if accompanied with MDR. The aim of the present study was to detect the prevalence, molecular mechanisms of resistance, and clonal relatedness of MDRGNB among third-generation cephalosporinresistant GN clinical isolates from Egypt.

\section{Materials and methods}

\section{Bacterial strains and antibiotic susceptibility testing}

A total of 118 GN clinical isolates collected during 20092010, previously identified with API 20E and API 20NE systems (BioMérieux, France) with an identity of not less than $80 \%$, were included in this study. They were selected from our culture collection based on their resistance to at least one of the third-generation cephalosporins. All isolates were from children with suspected infections in Abu El-Rish Children's Hospital, Cairo, Egypt. ${ }^{9}$ The isolates had been taken from different specimens: blood $(n=3)$, catheter tips $(n=3)$, cerebrospinal fluid $(n=8)$, ear discharge $(n=1)$, endotracheal tubing $(n=20)$, midline subumbilical gaps $(n=1)$, peritoneal discharge $(n=4)$, pus $(n=4)$, sputum $(n=18)$, stool $(n=9)$, urine $(n=43)$, and wounds $(n=5)$. All experiments in this study were conducted in accordance with and approval of the ethical committee at the Faculty of Pharmacy, Cairo University.

The antibiotic susceptibility of each isolate against its assigned categories of antimicrobials, as suggested by Magiorakos et al, ${ }^{1}$ was determined using Kirby-Bauer disk diffusion method following Clinical and Laboratory Standards Institute guidelines. ${ }^{10}$ Stenotrophomonas maltophilia was tested against the antimicrobial categories suggested by Milne and Gould. ${ }^{11}$ The antibiotics included in the study were gentamicin $10 \mu \mathrm{g}$, tobramycin $10 \mu \mathrm{g}$, amikacin $30 \mu \mathrm{g}$, ciprofloxacin $5 \mu \mathrm{g}$, cefoxitin $30 \mu \mathrm{g}$, piperacillin $100 \mu \mathrm{g}$, piperacillin-tazobactam 100 and $10 \mu \mathrm{g}$, sulfamethoxazoletrimethoprim 1.25 and $23.75 \mu \mathrm{g}$, imipenem $10 \mu \mathrm{g}$, ofloxacin $5 \mu \mathrm{g}$, cefepime $30 \mu \mathrm{g}$, aztreonam $30 \mu \mathrm{g}$, ampicillin-sulbactam $10 \mu \mathrm{g}$ each, cefotaxime $30 \mu \mathrm{g}$, and ceftazidime $30 \mu \mathrm{g}$ (all Oxoid; Thermo Fisher Scientific, Waltham, MA, USA). Isolates were classified as MDR and non-MDR according to Magiorakos et al. ${ }^{1}$ Intermediate susceptibility to any tested antibiotic was counted as resistant during the classification.

\section{Identification of efflux pump-mediated resistance using efflux-pump inhibitor- based microplate assays}

Chlorpromazine (CPZ; Hongda Pharmaceutical, Donggang, China) acts as an efflux-pump inhibitor in GN bacteria. ${ }^{12}$ The minimum inhibitory concentration (MIC) of CPZ was determined by the microdilution method as per Clinical and Laboratory Standards Institute guidelines in all tested MDR clinical isolates. ${ }^{13}$ Efflux-pump inhibitor-based microplate assays using half the minimum inhibitory concentration of CPZ were performed in 24-well microplates (Thermo Fisher Scientific). Negative bacterial growth in a well containing an antibiotic disk besides CPZ and positive growth in a well containing the same antibiotic disk alone indicated efflux pump-mediated resistance to that antibiotic. ${ }^{14}$

\section{Detection of antibiotic-resistance genes}

Genomic DNA was extracted from MDR clinical isolates by the boiling method. ${ }^{15}$ Polymerase chain reaction (PCR) identification of aminoglycoside-resistance genes (arm $\mathrm{A}$ and $\left.a a c\left(6^{\prime}\right)-I b\right), \beta$-lactamase-resistance genes $\left(\left(b l a_{\mathrm{TEM}}\right.\right.$ ' $b l a_{\mathrm{SHV},}$ bla ${ }_{\text {СтХ-м }}$ group 1 and group 9), metallo- $\beta$-lactamaseresistance genes $\left(b l a_{\mathrm{IMP}}, b l a_{\mathrm{VIM}}, b l a_{\mathrm{SPM}-1}, b l a_{\mathrm{NDM}}, b l a_{\mathrm{OXA}-23-\text { like }}\right)$ 
and quinolone-resistance genes (qep $\mathrm{A}, q n r \mathrm{~A}, q n r \mathrm{~B}$ and $q n r \mathrm{~S}$ ) was performed as previously described. ${ }^{16-23}$ Sequences of the resistance-genes primers used in the study and their annealing temperatures are provided in Table 1. When necessary, PCR products were purified with a GeneJet PCR purification kit (Thermo Fisher Scientific). PCR products of $a a c\left(6^{\prime}\right)-I b$ positives were analyzed further by digestion with BstF5I (Thermo Fisher Scientific) to detect the cr variant. ${ }^{18}$ The purified PCR products were sequenced by an ABI 3730 XL DNA sequencer (Thermo Fisher Scientific). Detection of similarity for nucleotide sequences was performed using the BLAST program (http://www.ncbi.nlm.nih.gov/blast) with default settings.

\section{Detection of genetic diversity of MDR isolates using random amplification of polymorphic DNA}

Clonal relatedness between isolates from the same species was assessed by random amplification of polymorphic DNA (RAPD) using at least two primers for each tested species. ${ }^{24-27}$ Sequences of RAPD primers used in the study are provided

Table I Primers used for detection of resistance genes and RAPD typing, annealing temperatures $\left(\mathrm{T}_{\mathrm{a}}\right)$, and expected product sizes

\begin{tabular}{|c|c|c|c|c|c|}
\hline Primer & Sequence (5'-3') & Target gene & $\mathbf{T}_{\mathbf{a}}$ & $\begin{array}{l}\text { Product } \\
\text { size }\end{array}$ & Reference \\
\hline armA-F & ATT CTG CCT ATC CTA ATT GG & I6S RNA methylase armA & $55^{\circ} \mathrm{C}$ & $315 \mathrm{bp}$ & 16 \\
\hline $\operatorname{armA-R}$ & ACC TAT ACT TTA TCG TCG TC & & & & \\
\hline aac $\left(6^{\prime}\right)-\mathrm{lb}-\mathrm{F}$ & TTGCGATGCTCTATGAGTGGCTA & $a a c\left(6^{\prime}\right)-I b$ & $54^{\circ} \mathrm{C}$ & 482 bp & 18 \\
\hline aac(6')-lb-R & CTCGAATGCCTGGCGTGTTT & & & & \\
\hline MultiTSO-T-F & CATTTCCGTGTCGCCCTTATTC & TEM variants, including TEMI and & $60^{\circ} \mathrm{C}$ & 800 bp & 20 \\
\hline MultiTSO-T-R & CGTTCATCCATAGTTGCCTGAC & TEM2 & & & \\
\hline MultiTSO-S-F & AGCCGCTTGAGCAAATTAAAC & SHV variants, including SHVI & $60^{\circ} \mathrm{C}$ & $713 \mathrm{bp}$ & 20 \\
\hline MultiTSO-S-R & ATCCCGCAGATAAATCACCAC & & & & \\
\hline MultiCTXMGpI-F & TTAGGAARTGTGCCGCTGYA ${ }^{\mathrm{a}}$ & Variants of CTXM group I & $60^{\circ} \mathrm{C}$ & 688 bp & 20 \\
\hline MultiCTXMGpI-R & CGATATCGTTGGTGGTRCCAT ${ }^{\mathrm{a}}$ & & & & \\
\hline MultiCTXMGp9-F & TCAAGCCTGCCGATCTGGT & Variants of CTXM group 9 & $60^{\circ} \mathrm{C}$ & 561 bp & 20 \\
\hline MultiCTXMGp9-R & TGATTCTCGCCGCTGAAG & & & & \\
\hline MultilMP-F & TTGACACTCCATTTACDGa & IMP variants & $55^{\circ} \mathrm{C}$ & 139 bp & 20 \\
\hline MultilMP-R & GATYGAGAATTAAGCCACYCT ${ }^{a}$ & & & & \\
\hline MultiVIM-F & GATGGTGTTTGGTCGCATA & VIM variants & $55^{\circ} \mathrm{C}$ & $390 \mathrm{bp}$ & 20 \\
\hline MultiVIM-R & CGAATGCGCAGCACCAG & & & & \\
\hline Spm-F & AAA ATC TGG GTA CGC AAA CG & SPMI & $52^{\circ} \mathrm{C}$ & $271 \mathrm{bp}$ & 23 \\
\hline Spm-R & ACA TTA TCC GCT GGA ACA GG & & & & \\
\hline NDM-F & GGT TTG GCG ATC TGG TTT TC & NDM variants & $52^{\circ} \mathrm{C}$ & $621 \mathrm{bp}$ & 21 \\
\hline NDM-R & CGG AAT GGC TCA TCA CGA TC & & & & \\
\hline OXA-23-like-F & GAT CGG ATT GGA GAA CCA GA & OXA23-like & $53^{\circ} \mathrm{C}$ & 501 bp & 22 \\
\hline OXA-23-like-R & ATT TCT GAC CGC ATT TCC AT & & & & \\
\hline qepA-F & GCA GGT CCA GCA GCG GGT AG & qepA & $60^{\circ} \mathrm{C}$ & 199 bp & 17 \\
\hline qepA-R & CTT CCT GCC CGA GTA TCG TG & & & & \\
\hline QnrA-F & AGAGGATTTCTCACGCCAGG & $q n r A$ & $54^{\circ} \mathrm{C}$ & 580 bp & 19 \\
\hline QnrA-R & TGCCAGGCACAGATCTTGAC & & & & \\
\hline QnrB-F & GGMATHGAAATTCGCCACTG ${ }^{b}$ & $q n r B$ & $54^{\circ} \mathrm{C}$ & 264 bp & 19 \\
\hline QnrB-R & TTTGCYGYYCGCCAGTCGAA & & & & \\
\hline QnrS-F & GCAAGTTCATTGAACAGGGT & qnrS & $54^{\circ} \mathrm{C}$ & 428 bp & 19 \\
\hline QnrS-R & TCTAAACCGTCGAGTTCGGCG & & & & \\
\hline 208 & ACGGCCGACC & & $36^{\circ} \mathrm{C}$ & & \\
\hline 272 & AGCGGGCCAA & RAPD for Pseudomonas aeruginosa & $36^{\circ} \mathrm{C}$ & & 24 \\
\hline ERICI & ATGTAAGCTCCTGGGGATTCAC & & $35^{\circ} \mathrm{C}$ & & \\
\hline ERIC2 & AAGTAAGTGACTGGGGTGAGCG & RAPD for Klebsiella pneumoniae & $25^{\circ} \mathrm{C}$ & & 25 \\
\hline RAPD7 & GTGGATGCGA & & $35^{\circ} \mathrm{C}$ & & 26 \\
\hline 1247 & AAGAGCCCGT & & $36^{\circ} \mathrm{C}$ & & \\
\hline 1281 & AACGCGCAAC & RAPD for Escherichia coli and & & & 27 \\
\hline 1283 & GCGATCCCCA & Acinetobacter baumannii & & & \\
\hline
\end{tabular}

Notes: ${ }^{\mathrm{Y}} \mathrm{Y}=\mathrm{T}$ or $\mathrm{C} ; \mathrm{R}=\mathrm{A}$ or $\mathrm{G} ; \mathrm{D}=\mathrm{A}$ or $\mathrm{G}$ or $\mathrm{T}$; $\mathrm{b} \mathrm{M}=\mathrm{A}$ or $\mathrm{C} ; \mathrm{H}=\mathrm{A}$ or $\mathrm{C}$ or $\mathrm{T} ; \mathrm{Y}=\mathrm{C}$ or $\mathrm{T}$.

Abbreviation: RAPD, random amplification of polymorphic DNA. 
in Table 1. Amplicons were separated by $1.5 \%$ agarose-gel electrophoresis using a GeneRuler 100 bp ladder (Thermo Fisher Scientific) as a molecular size standard in each gel. Gels were stained with ethidium bromide and photographed under ultraviolet transillumination. Gel images were analyzed by GelAnalyzer 2010. The absence or presence of a band of a certain size was recorded as 0 or 1 . For each strain, the RAPD type was defined as the combined band patterns obtained with the tested primers. The relationship between the RAPD types of isolates of the same species were calculated by unweighted pair-group (UPG) averages and represented as a dendrogram using UPGMA algorithms. In any tested isolate, banding patterns differing by two or more bands represented different strains, while banding patterns that differed by fewer than two bands were the same strain. ${ }^{25}$

\section{Results}

\section{Bacterial strains and antibiotic- susceptibility testing}

A total of $118 \mathrm{GN}$ clinical isolates characterized as being resistant to at least one of the third-generation cephalosporins were included in the study, and 100 isolates (84.75\%) were classified as MDR: Acinetobacter baumannii (13 of 15, 86.6\%), Escherichia coli (37 of 38, 97.37\%), K. pneumoniae (21 of 22, 95.45\%), Pseudomonas aeruginosa (17 of 26, 65.38\%), S. maltophilia (three of four, 75\%), and other Enterobacteriaceae (nine of 13, 69.23\%). MDR and nonMDR distribution among third-generation cephalosporinresistant GN clinical isolates from different infection sites is shown in Figure 1. The antibiotic-susceptibility profile of each tested isolate is shown in Table S1.

A. baumanii isolates were resistant to most of the tested antibiotics. Imipenem was the most effective antibiotic against tested Enterobacteriaceae and P. aeruginosa. All
S. maltophilia isolates were susceptible to ofloxacin, ciprofloxacin, cefepime, piperacillin, piperacillin-tazobactam and sulfamethoxazole-trimethoprim. The number of resistant isolates in every tested bacterial species for each of the tested antibiotics is shown in Table 2 and Figure 2.

\section{Identification of efflux pump-mediated resistance using efflux-pump inhibitor- based microplate assays}

Efflux pump-mediated resistance was recorded in $46.1 \%$ (six of 13 ), $41.1 \%$ (seven of 17 ), $40.54 \%$ (15 of 37 ), $66.67 \%$ (14 of 21 ), $66.67 \%$ (two of three), and $66.67 \%$ (six of nine) of MDR A. baumannii, P. aeruginosa, E. coli, K. pneumoniae, $S$. maltophilia, and other Enterobacteriaceae, respectively. Efflux pump-mediated resistance for more than one antibiotic was recorded in five of 13 and nine of 21 of MDR A. baumannii and $K$. pneumoniae, respectively. However, this multidrug efflux pump-mediated resistance was of lower incidence in other tested species. The number of isolates in each tested species displaying different patterns of efflux-mediated resistance is shown in Table 3. Efflux pump-mediated resistance to different antibiotics in each MDRGNB isolate is shown in Table S2.

\section{Antibiotic-resistance genes}

The sequenced products were deposited in the GenBank under accession numbers KY640457-KY640597. The incidence of each tested gene in the different species of MDRGNB clinical isolates tested is recorded in Table 4, and their distribution in the different MDRGNB isolates is shown in Table S3. All detected bla $a_{\text {TEM }}$ were TEM1 variants, while, bla ${ }_{\mathrm{SHV}}$ were SHV1, SHV11, SHV12, and SHV31 variants. Group 1 bla $a_{\text {СтХ-м }}$ ESBL-resistance genes belonged to type CTXM15, while bla $a_{\text {СтХ-м }}$ group 9 belonged to type

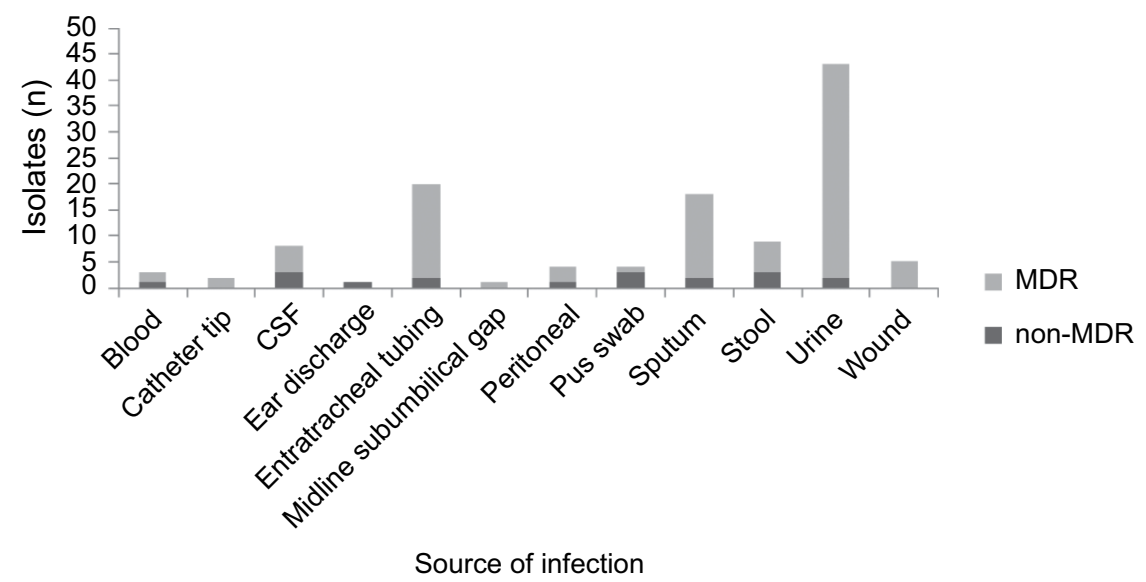

Figure I Distribution of MDR and non-MDR phenotypes among third-generation cephalosporin resistant Gram-negative clinical isolates from different infection sites. Abbreviations: MDR, multidrug-resistant; CSF, cerebrospinal fluid. 


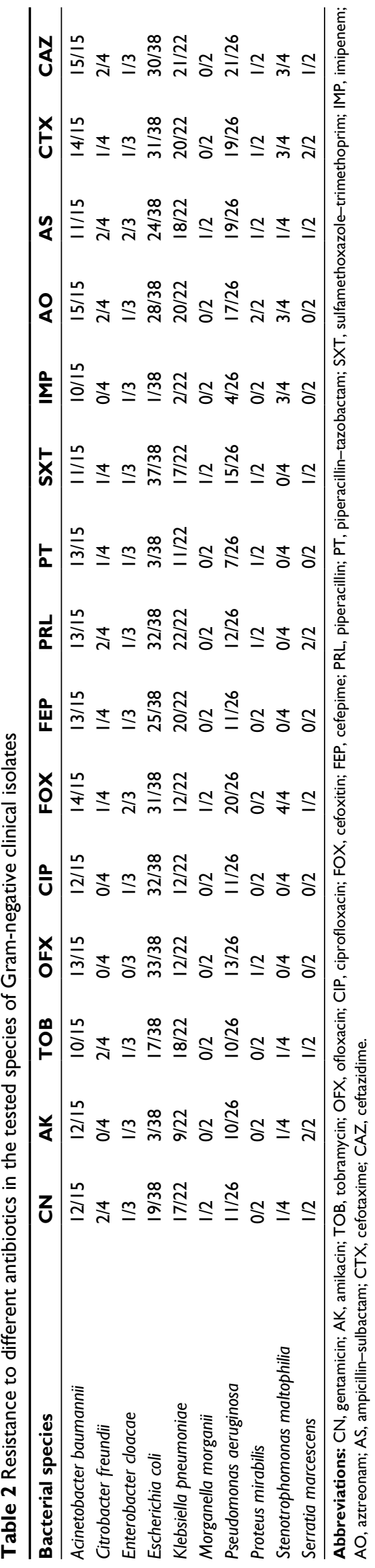

CTXM14. The metallo- $\beta$-lactamase resistance genes $b l a_{\mathrm{IMP}}$, $b l a_{\mathrm{SPM}-1}$, and $b l a_{\mathrm{NDM}}$ and quinolone-resistance genes: qepA and $q n r \mathrm{~A}$ were not detectable in our tested MDRGNB clinical isolates.

\section{Determination of genetic diversity of MDR isolates using RAPD}

The number of clonal patterns detected in MDRGNB isolates was 34 of 37, ten of 13, 18 of 21, and 17 of 26 patterns in E. coli, A. baumannii, K. pneumoniae, and P. aeruginosa isolates, respectively. No predominant clonal type was detectable with $E$. coli or P. aeruginosa isolates. However, five of 13 of $A$. baumannii isolates belonged to two clonal types, and three of 21 of $K$. pneumoniae isolates belonged to one clonal type. Clonally identical isolates shared the same antibiotic-resistance pattern $(8,27$, and $146 ; 150$, and 179 in A. baumanii and 161, 163, and 223 in K. pneumoniae), although they had different infection sites. Phenograms constructed using UPGMA algorithms for MDR isolates are shown in Figure S1.

\section{Discussion}

Few reports are available on the prevalence and mechanisms of MDR in GNB in developing countries including Egypt. ${ }^{6,7}$ Therefore, our study was carried out to determine the prevalence, molecular resistance mechanisms, and clonal relatedness of MDRGNB among third-generation cephalosporin-resistant isolates from Egypt. Our findings showed that $84.75 \%$ of the third-generation cephalosporin-resistant isolates were classified as MDR, with the highest percentage of MDR recorded in E. coli, followed by K. pneumoniae and A. baumannii. Various international surveys have reported an increase in the number of MDRGNB in the last few years. ${ }^{28}$

One of the alarming results was the resistance of A. baumanii isolates to most of the antibiotics tested, including imipenem. Carbapenems are considered one of the last-resort antimicrobials for $\mathrm{GNB},{ }^{29}$ and resistance to carbapenems leaves few effective therapeutic options, such as polymyxins or tigecycline. ${ }^{5}$ This high level of imipenem resistance (ten of 13) may result from the high number of $b l a_{\text {OXA-23 }}$-like genes detected among MDR A. baumanii (nine of 13), as previously reported. ${ }^{5}$ This is in accordance with the results of Al-Agamy et al from Egypt, where $b l a_{\text {OXA-23 }}$ and $b l a_{\text {OXA-24 }}$-like genes were found to be the most prevalent type of $\beta$-lactamase-encoding genes in A. baumannii. ${ }^{30}$ Effluxmediated resistance accounted for this MDR phenotype in A. baumannii (six of 13), half of which (three of six) contained multidrug-efflux pumps that mediated resistance to 


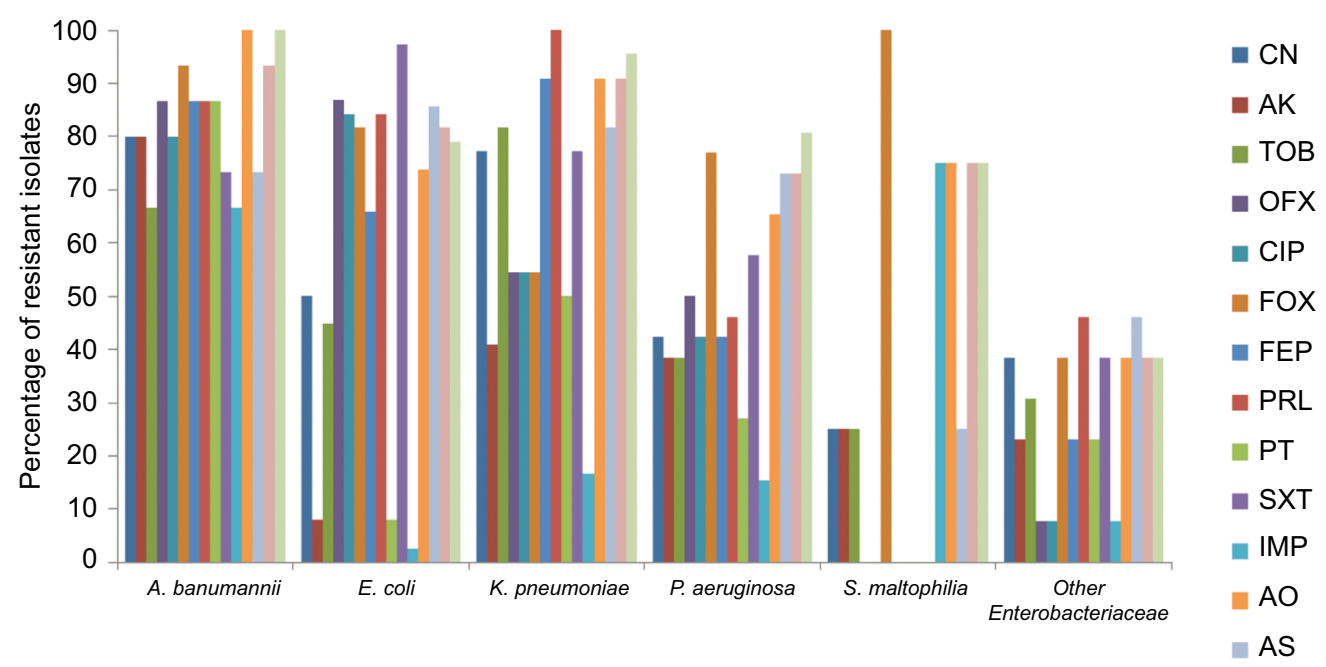

Figure 2 Percentage of isolates resistant to each antimicrobial tested within the different bacterial species.

Abbreviations: CN, gentamicin; AK, amikacin; TOB, tobramycin; OFX, ofloxacin; CIP, ciprofloxacin; FOX, cefoxitin; FEP, cefepime; PRL, piperacillin; PT, piperacillintazobactam; SXT, sulfamethoxazole-trimethoprim; IMP, imipenem; AO, aztreonam; AS, ampicillin-sulbactam.

gentamicin, ciprofloxacin, sulfamethoxazole-trimethoprim, and piperacillin. A previous study in Egypt reported a higher percentage of efflux pumps (77.8\%) in A. baumannii isolates. ${ }^{31}$ In accordance with previous studies, ${ }^{5}$ aminoglycoside resistance was common among our isolates. This may have been due to the presence of $a a c-\left(6^{\prime}\right)-I b$ gene-and efflux pump-mediated gentamicin resistance in nine of 12 and five of 12 of aminoglycoside-resistant MDR A. baumanii isolates, respectively.

In agreement with the reported susceptibility pattern of P. aeruginosa, ${ }^{5}$ most of our isolates were sensitive to imipenem (84\%) and piperacillin-tazobactam (73\%). On the contrary, $65 \%$ of $P$. aeruginosa isolates were MDR, of which only $23.5 \%$ showed multidrug efflux-mediated resistance. This is in contrast to the known major contribution of efflux pumps in MDR P. aeruginosa. ${ }^{5}$ The metallo- $\beta$-lactamase-resistance gene $b l a_{\mathrm{VIM}}$ was detected in one P. aeruginosa isolate. This represented $5.88 \%$ of MDR $P$. aeruginosa clinical isolates and $33.33 \%$ of $P$. aeruginosa isolates resistant to imipenem. Other studies in Egypt reported higher prevalence of bla ${ }_{\mathrm{VIM}}$ in $P$. aeruginosa clinical isolates..$^{32,33}$

All our S. maltophilia isolates were sensitive to sulfamethoxazole-trimethoprim, the cornerstone in the treatment of this pathogen, ${ }^{5}$ and to the tested fluoroquinolones (ciprofloxacin and ofloxacin). Most isolates (three of four) were sensitive to $\beta$-lactam/ $\beta$-lactamase inhibitor combinations. Fluoroquinolones and $\beta$-lactam/ $\beta$-lactamase inhibitor combinations have been reported to be among the most effective agents against $S$. maltophilia. ${ }^{5}$ Although S. maltophilia are known to be aminoglycoside-resistant, ${ }^{5}$ only one isolate (of three) was resistant to the three tested aminoglycosides, and showed efflux-mediated resistance to aminoglycosides. Efflux pumps are one of the known resistance mechanisms in S. maltophilia. ${ }^{5}$ Predominant resistance to aztreonam, cephalosporins, and imipenem in S. maltophilia, has been reported in the literature. ${ }^{5}$

About $76 \%$ of the MDR Enterobacteriaceae contained at least one of the tested $\beta$-lactam-resistance genes, where $\beta$-lactamases are commonly reported among Enterobacteriaceae. ${ }^{5}$ In addition, efflux-mediated resistance to piperacillin ( $\beta$-lactam) was recorded in $47.5 \%$ of piperacillin-resistant MDR Enterobacteriaceae. This highlights the major role played by efflux pumps in resistance to $\beta$-lactams in MDR Enterobacteriaceae. A lower predominance of efflux pumpmediated resistance (39\%) was reported among MDR K. pneumoniae isolates in Turkey. ${ }^{34}$

The bla $_{\text {TEM-1 }}$ gene was common in our MDR Enterobacteriaceae isolates and was the only detected $\beta$-lactamaseresistance gene in $6 \%$ of them. This is in agreement with previous studies showing the high persistence of the bla $a_{\text {TEM-1 }}$ gene among Enterobacteriaceae worldwide. ${ }^{35}$ The $\beta$-lactamase-resistance gene $b l a_{\mathrm{SHV}}$ was detected in $28.3 \%$ of MDR Enterobacteriaceae and identified by sequencing as variants SHV1, SHV11, SHV12 and SHV31 in 79\%, $10.5 \%, 5 \%$, and $5 \%$ of $b l a_{\mathrm{SHV}}$-positive isolates, respectively. This was in contrast to another study from Egypt that detected only SHV1 and SHV11 in 57\% and $29 \%$ of $b l a_{\mathrm{SHV}}$-containing isolates, respectively. ${ }^{36}$ To the best of our knowledge, this is the first report on the occurrence of SHV31 in MDR K. pneumoniae isolates from Egypt, Africa, and the Middle East. Isolates were recovered from an endotracheal tube specimen, and were also positive for 


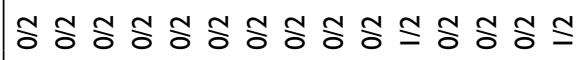
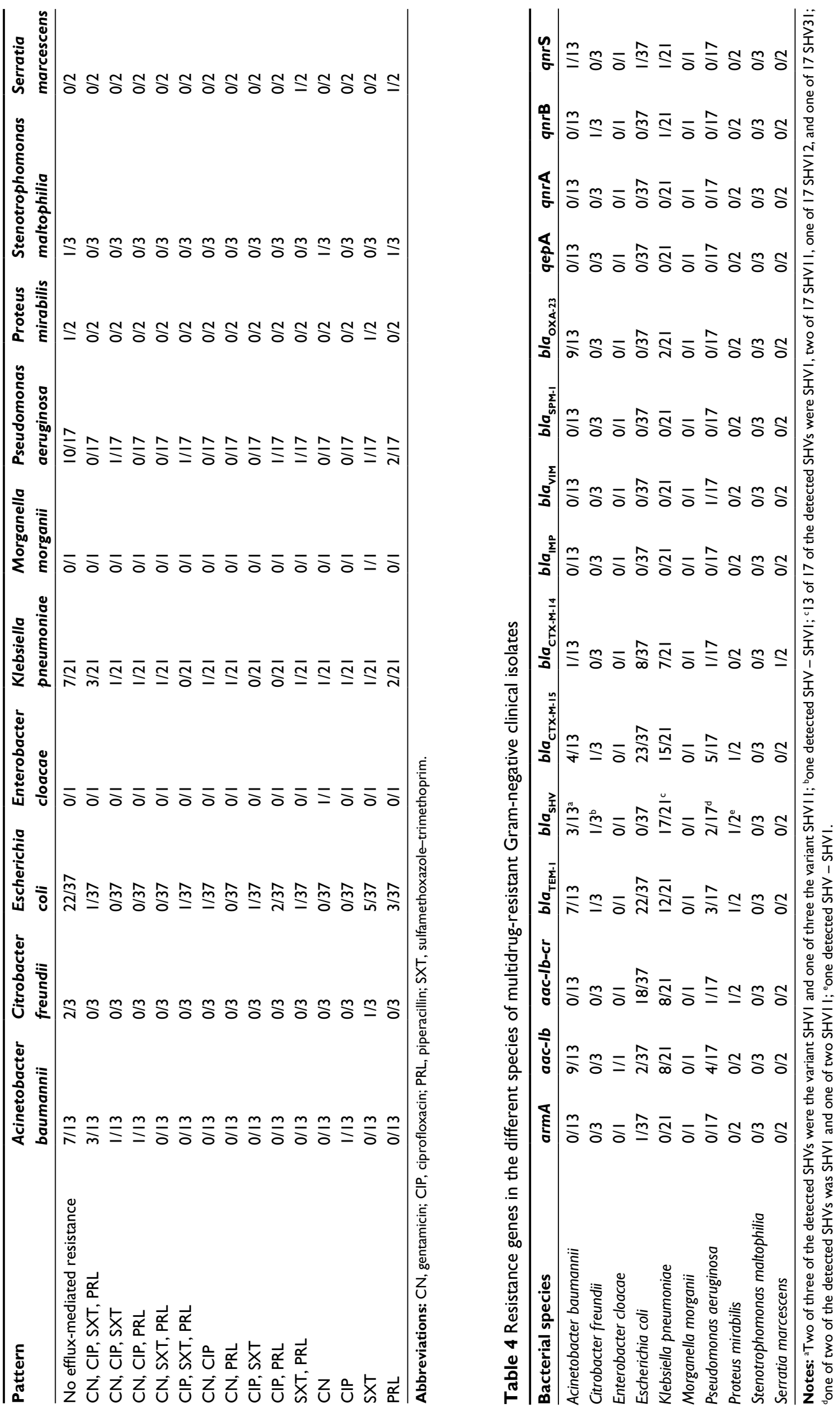
$b l a_{\text {TЕM-1 }}, b l a_{\text {СТХ-M-15 }}, b l a_{\text {СТХ-м-14 }}, a a c\left(6^{\prime}\right)-I b-c r, q n r \mathrm{~S}$, and multidrug efflux-mediated resistance. The SHV31 variant has limited dissemination worldwide. It has been detected only in K. pneumoniae in the Netherlands (2001), Brazil (2005-2007), Iran (2006-2007), and Taiwan. ${ }^{37}$

ESBL-resistance genes $b l a_{\text {CTX-M-15 }}$ and $b l a_{\text {CTX-M-14 }}$ were detected in $60 \%$, and $24 \%$ of our MDR Enterobacteriaceae. This is in agreement with the worldwide prevalence of CTXM15 and CTXM14. ${ }^{38}$ Our findings are comparable with another study conducted in Egypt on $\beta$-lactamase prevalence in Enterobacteriaceae ${ }^{39}$ In a similar study conducted in India, $66 \%$ of thirdgeneration cephalosporin-resistant $E$. coli and $K$. pneumoniae isolates had $b l a_{\mathrm{CTX}-\mathrm{M}-15{ }^{5}}{ }^{40}$ Moreover, $b l a_{\text {OXA-23 }}$-like, mainly detectable in A. baumannii ${ }^{30}$ was detected in two of $21 \mathrm{~K}$. pneumoniae isolates. The detection of $b l a_{\text {OXA-23 }}$-like in K. pneumoniae has previously been reported in the literature. ${ }^{41}$

Fluoroquinolone resistance in Enterobacteriaceae results mainly from mutations in DNA gyrase and topoisomerase genes. ${ }^{5}$ It was surprising to detect the plasmid-mediated quinolone-resistance genes ( $a a c\left(6^{\prime}\right)-I b-c r$, qnr $\mathrm{B}$, and $q n r \mathrm{~S}$ ) in $57.6 \%$ (19 of 33 ) and $83.33 \%$ (ten of 12 ) of quinoloneresistant MDR E. coli and K. pneumoniae, respectively. These determinants have been detected worldwide with high prevalence among K. pneumoniae. ${ }^{42}$ The aac (6')-Ib-cr gene, which confers resistance to ciprofloxacin and norfloxacin besides aminoglycosides, was prevalent in MDR E. coli isolates (48.6\%), although lower incidence has previously been detected in Egypt (23.3\%). ${ }^{43}$

The aminoglycoside-modifying enzyme (aac (6')$I b$ ) was detected in $84.4 \%$ of aminoglycoside-resistant Enterobacteriaceae. The role of modifying enzymes in aminoglycoside resistance has been documented. ${ }^{5}$ However, efflux-mediated gentamicin resistance was detected in $26.6 \%$ of aminoglycoside-resistant MDR Enterobacteriaceae. This again reflects the growing role of efflux pumps in mediating MDR among members of Enterobacteriaceae in Egypt.

The copresence of different classes of resistance genes was common among our isolates (Table S3). This is alarming, as it presents an antibiotic selection advantage for these isolates to predominate as MDR. It is also worth noting that 17 of the MDRGNB isolates carried none of the tested $\beta$-lactamase genes nor exhibited efflux pump-mediated resistance. It is likely that these isolates carry one or more $\beta$-lactamase genes not tested in this study or contain efflux pumps that could not be detected by the efflux-pump inhibitor used.

The MDR species tested were genotypically variable. This suggested that multiple subtypes of the species were involved in MDR and opposed the probability that MDR may have resulted from clonal spread. The only limitation of this study was the small number of isolates tested in some species, which made it difficult to draw solid conclusions about these organisms.

\section{Conclusion}

MDR is predominant among third-generation cephalosporin-resistant GNB in Egypt. In most cases, resistance is caused by different mechanisms. This study highlighted the increasing role of efflux pumps and the increase in plasmid-mediated quinolone resistance among MDR Enterobacteriaceae. Therefore, new treatment strategies need to be implemented. The use of an efflux-pump inhibitor combined with old antibiotics can provide a possible treatment for infections caused by efflux-mediated resistant bacteria, maintaining the effectiveness of old antibiotics. Moreover, antibiotic misuse needs to be stopped to avoid the selection of MDR species.

\section{Acknowledgment}

The abstract for this study was published in the International Journal of Medical and Health Sciences, 2016;3(5).

\section{Disclosure}

The authors report no conflicts of interest in this work.

\section{References}

1. Magiorakos AP, Srinivasan A, Carey RB, et al. Multidrug-resistant, extensively drug-resistant and pandrug-resistant bacteria: an international expert proposal for interim standard definitions for acquired resistance. Clin Microbiol Infect. 2012;18(3):268-281.

2. Ibrahim EH, Sherman G, Ward S, Fraser VJ, Kollef MH. The influence of inadequate antimicrobial treatment of bloodstream infections on patient outcomes in the ICU setting. Chest. 2000;118(1):146-55.

3. McGowan JE. Resistance in nonfermenting Gram-negative bacteria: multidrug resistance to the maximum. Am JMed. 2006;119(6):S29-S36.

4. Boucher HW, Talbot GH, Bradley JS, et al. Bad bugs, no drugs: no ESKAPE! An update from the Infectious Diseases Society of America. Clin Infect Dis. 2009;48(1):1-12.

5. Ruppé E, Woerther P, Barbier F. Mechanisms of antimicrobial resistance in Gram-negative bacilli. Ann Intensive Care. 2015;5(1):21.

6. Abdelkader MA, Aboshanab KM, El-Ashry MA, et al. Prevalence of MDR pathogens of bacterial meningitis in Egypt and new synergistic antibiotic combinations. PLoS One. 2017;12 (2):e0171349.

7. Mohsen L, Ramy N, Saied D, et al. Emerging antimicrobial resistance in early and late-onset neonatal sepsis. Antimicrob Resist Infect Control. 2017;6:63.

8. Talaat M, Saied T, Kandeel A, et al. A point prevalence survey of antibiotic use in 18 hospitals in Egypt. Antibiotics (Basel). 2014;3(3):450-460.

9. Kashif MT, Yassin AS, Hosny AD. Detection of AmpC beta-lactamases using sodium salicylate. J Microbiol Methods. 2012;91(3):354-357.

10. Clinical and Laboratory Standards Institute. Performance Standards for Antimicrobial Disk Susceptibility Tests. 11th ed. Wayne (PA): CLSI; 2012. 
11. Milne KE, Gould IM. Combination antimicrobial susceptibility testing of multidrug-resistant Stenotrophomonas maltophilia from cystic fibrosis patients. Antimicrob Agents Chemother. 2012;56(8):4071-4077.

12. Kristiansen JE, Thomsen VF, Martins A, Viveiros M, Amaral L. Non-antibiotics reverse resistance of bacteria to antibiotics. In Vivo. 2010;24(5):751-754.

13. Clinical and Laboratory Standards Institute. Antimicrobial Susceptibility Tests for Bacteria That Grow Aerobically. 9th ed. Wayne (PA): CLSI; 2012.

14. Martins M, Couto I, Viveiros M, Amaral L. Identification of effluxmediated multi-drug resistance in bacterial clinical isolates by two simple methods. In: Gillespie SH, McHugh TD, editors. Antibiotic Resistance Protocols. 2nd ed. Heidelberg: Springer; 2011.

15. Sambrook J, Russell D. Molecular Cloning: A Laboratory Manual. 3rd ed. Laurel Hollow (NY): Cold Spring Harbor Laboratory.

16. Doi Y, Arakawa Y. 16S ribosomal RNA methylation: emerging resistance mechanism against aminoglycosides. Clin Infect Dis. 2007;45(1):88-94

17. Yamane K, Wachino JI, Suzuki S, Arakawa Y. Plasmid-mediated qepA gene among Escherichia coli clinical isolates from Japan. Antimicrob Agents Chemother. 2008;52(4):1564-1566.

18. Park CH, Robicsek A, Jacoby GA, Sahm D, Hooper DC. Prevalence in the United States of AAC(6)-IB-cr encoding a ciprofloxacin-modifying enzyme. Antimicrob Agents Chemother. 2006;50(11):3953-3955.

19. Cattoir V, Poirel L, Rotimi V, Soussy CJ, Nordmann P. Multiplex PCR for detection of plasmid-mediated quinolone resistance Qnr genes in ESBL-producing enterobacterial isolates. J Antimicrob Chemother. 2007;60 (2):394-397.

20. Dallenne C, Da Costa A, Decré D, Favier C, Arlet G. Development of a set of multiplex PCR assays for the detection of genes encoding important $\beta$-lactamases in Enterobacteriaceae. JAntimicrob Chemother. 2010;65(3):490-495

21. Bora A, Ahmed G. Detection of NDM-1 in clinical isolates of Klebsiella pneumoniae from northeast India. J Clin Diagn Res. 2012;6(5):794-800.

22. Amudhan SM, Sekar U, Arunagiri K, Sekar B. OXA beta-lactamasemediated carbapenem resistance in Acinetobacter baumannii. Indian J Med Microbiol. 2011;29(3):269-274.

23. Ellington MJ, Kistler J, Livermore DM, Woodford N. Multiplex PCR for rapid detection of genes encoding acquired metallo- $\beta$-lactamases. J Antimicrob Chemother. 2007;59(2):321-322.

24. Lanini S, D'Arezzo S, Puro V, et al. Molecular epidemiology of a Pseudomonas aeruginosa hospital outbreak driven by a contaminated disinfectant-soap dispenser. PloS One. 2011;6(2):e17064.

25. Vogel L, Jones G, Triep S, Koek A, Dijkshoorn L. RAPD typing of Klebsiella pneumoniae, Klebsiella oxytoca, Serratia marcescens and Pseudomonas aeruginosa isolates using standardized reagents. Clin Microbiol Infect. 1999;5(5):270-276.

26. Gniadkowski M, Schneider I, Jungwirth R, Hryniewicz W, Bauernfeind A. Ceftazidime-resistant Enterobacteriaceae isolates from three Polish hospitals: identification of three novel TEM- and SHV-5-type extended-spectrum $\beta$-lactamases. Antimicrob Agents Chemother. 1998;42(3):514-520

27. Madico G, Akopyants NS, Berg DE. Arbitrarily primed PCR DNA fingerprinting of Escherichia coli O157:H7 strains by using templates from boiled cultures. J Clin Microbiol. 1995;33(6):1534-1536.
28. Centers for Disease Control and Prevention. Antibiotic Resistance Threats in the United States, 2013. Atlanta: CDC; 2014.

29. Papp-Wallace KM, Endimiani A, Taracila MA, Bonomo RA. Carbapenems: past, present, and future. Antimicrob Agents Chemother. 2011;55(11):4943-4960.

30. Al-Agamy MH, Khalaf NG, Tawfick MM, Shibl AM, El Kholy A. Molecular characterization of carbapenem-insensitive Acinetobacter baumannii in Egypt. Int J Infect Dis. 2014;22:49-54.

31. Gomaa FM, Tawakol WM, El-Azm FI. Phenotypic and genotypic detection of some antimicrobial resistance mechanisms among multidrugresistant Acinetobacter baumannii isolated from immunocompromised patients in Egypt. Egypt J Med Microbiol. 2014;23(4):99-111.

32. Zafer MM, Amin M, El Mahallawy H, Ashour MS, Al Agamy M. First report of NDM-1-producing Pseudomonas aeruginosa in Egypt. Int $J$ Infect Dis. 2014;29:80-1.

33. El Sayed HM, Fakhr AE, El Sayed HM, Al Johery SE, Hassanein WA. Spread of TEM, VIM, SHV, and CTX-M $\beta$-lactamases in imipenemresistant Gram-negative bacilli isolated from Egyptian hospitals. Int $J$ Microbiol. 2016;2016:8382605.

34. Hasdemir UO, Chevalier J, Nordmann P, Pagès JM. Detection and prevalence of active drug efflux mechanism in various multidrugresistant Klebsiella pneumoniae strains from Turkey. J Clin Microbiol. 2004;42(6):2701-2706.

35. Cantón R, Novais A, Valverde A, et al. Prevalence and spread of extended-spectrum $\beta$-lactamase-producing Enterobacteriaceae in Europe. Clin Microbiol Infect. 2008;14 Suppl 1:144-153.

36. Salah M, Azab M, Halaby H, Hanora A. Mutations in $\beta$-lactamases detected in multidrug resistant Gram-negative bacteria isolated from community acquired urinary tract infections in Assiut, Egypt. Afr $J$ Microbiol Res. 2016;10(46):1938-1943.

37. Liakopoulos A, Mevius D, Ceccarelli D. A review of SHV extendedspectrum $\beta$-lactamases: neglected yet ubiquitous. Front Microbiol. 2016;7:1374.

38. Zhao WH, Hu ZQ. Epidemiology and genetics of CTX-M extendedspectrum $\beta$-lactamases in Gram-negative bacteria. Crit Rev Microbiol. 2013;39(1):79-101.

39. Abdallah HM, Wintermans BB, Reuland EA, et al. Extended-spectrum $\beta$-lactamase-and carbapenemase-producing Enterobacteriaceae isolated from egyptian patients with suspected blood stream infection. PloS One. 2015;10(5):e0128120.

40. Ensor VM, Shahid M, Evans JT, Hawkey PM. Occurrence, prevalence and genetic environment of CTX-M $\beta$-lactamases in Enterobacteriaceae from Indian hospitals. JAntimicrob Chemother. 2006;58(6):1260-1263.

41. Evans BA, Amyes SG. OXA $\beta$-lactamases. Clin Microbiol Rev. 2014;27(2):241-263.

42. Kim HB, Park CH, Kim CJ, Kim EC, Jacoby GA, Hooper DC. Prevalence of plasmid-mediated quinolone resistance determinants over a 9-year period. Antimicrob Agents Chemother. 2009;53(2):639-645.

43. Hassan WM, Hashim A, Domany RA. Plasmid mediated quinolone resistance determinants qnr, aac (6')-Ib-cr, and qep in ESBL-producing Escherichia coli clinical isolates from Egypt. Indian J Med Microbiol. 2012;30(4):442-447. 


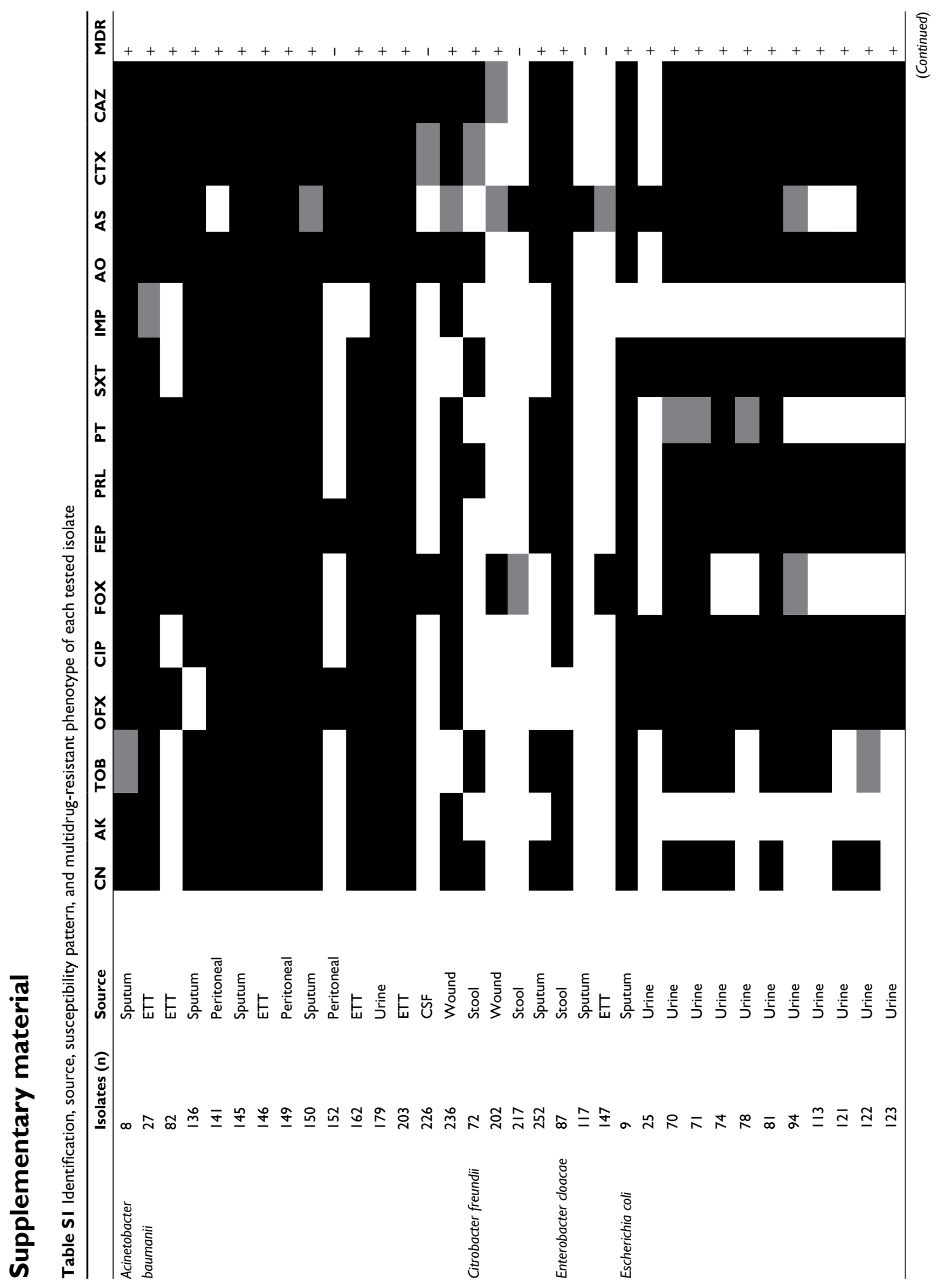




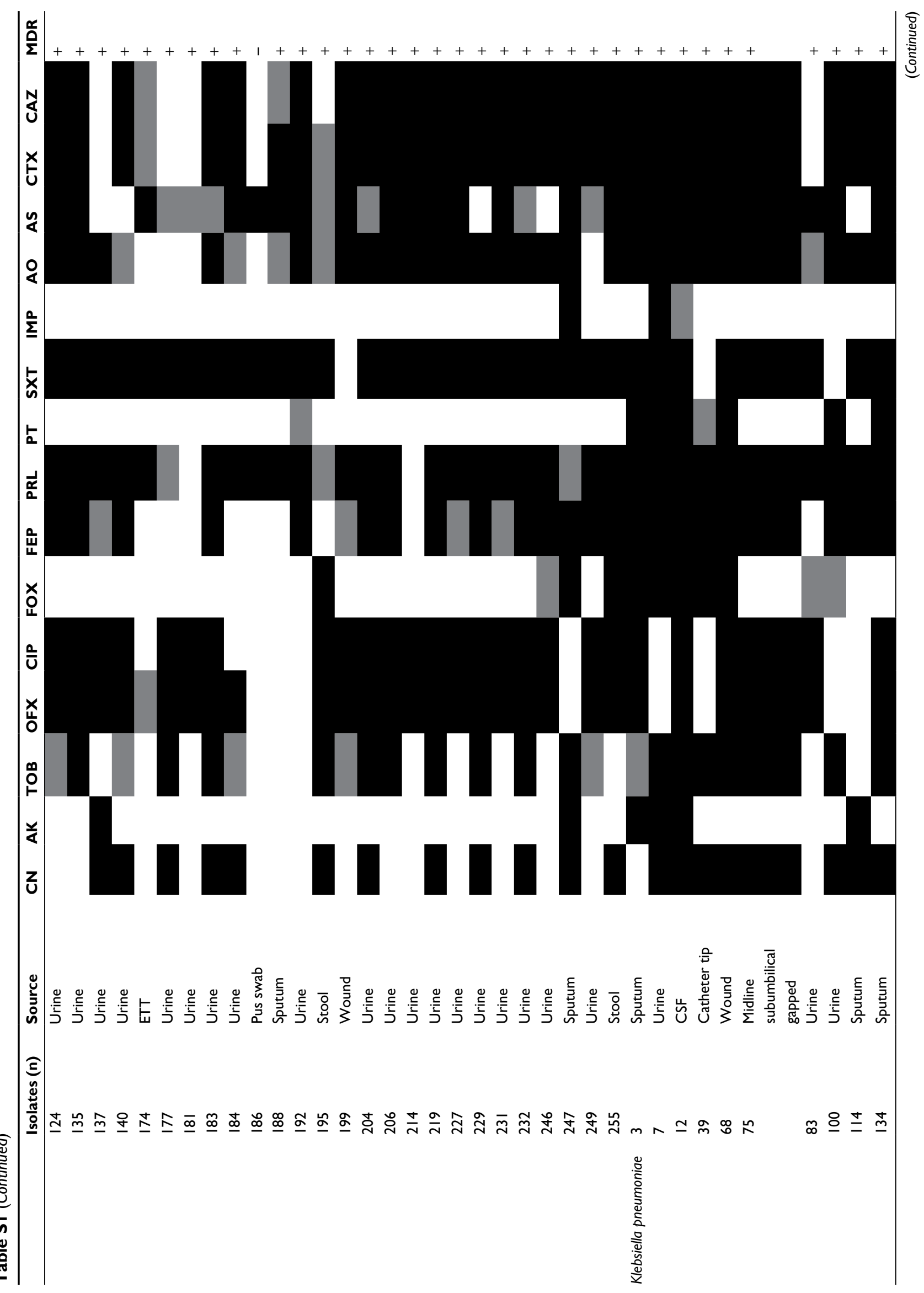




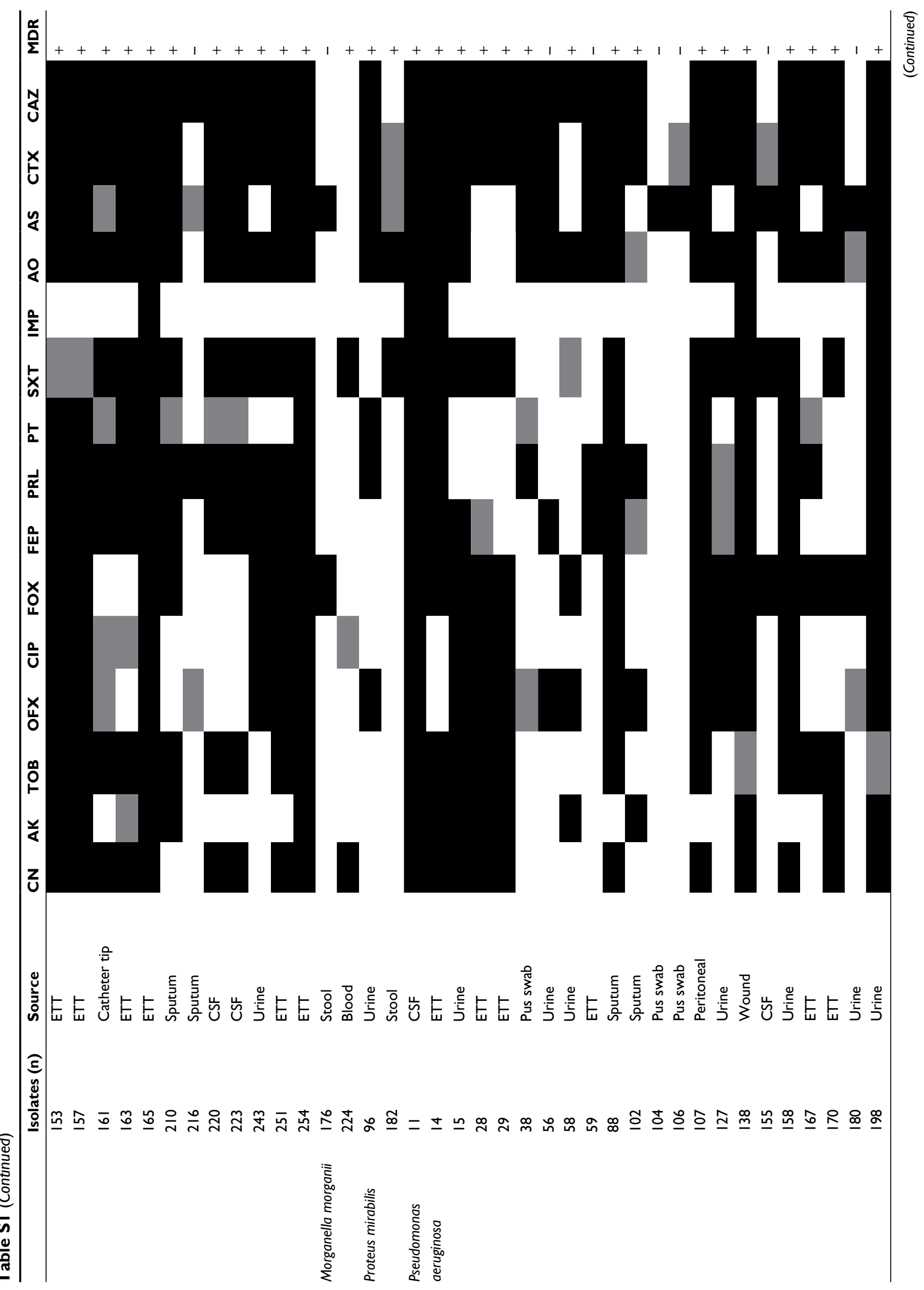




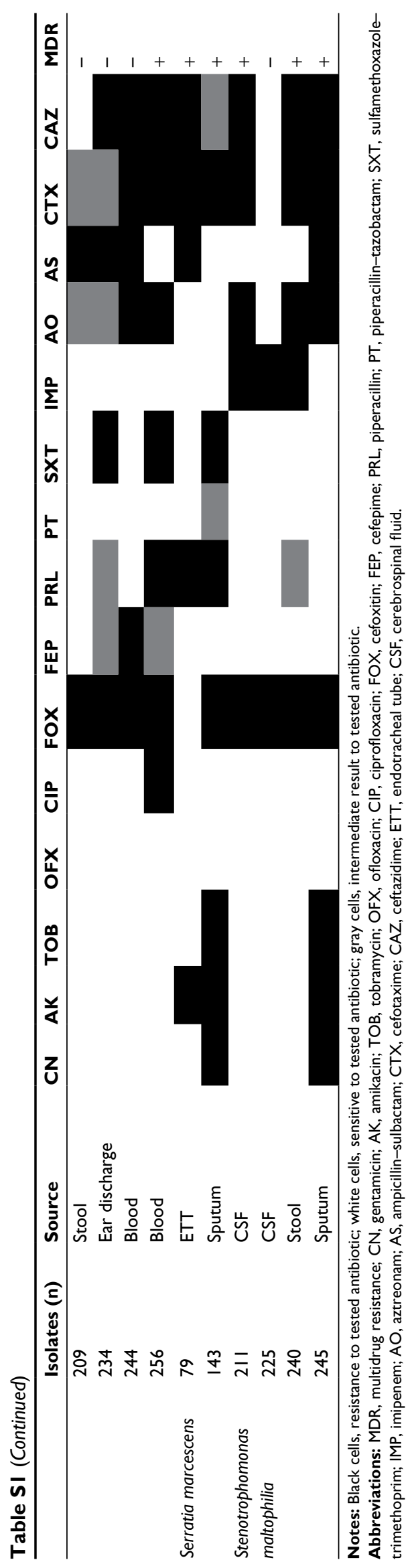


Table S2 Efflux-mediated resistance profile in each tested multidrug-resistant Gram-negative isolate

\begin{tabular}{|c|c|c|c|c|c|}
\hline & Isolate number & Gentamicin & Ciprofloxacin & Trimethoprim-sulfamethoxazole & Piperacillin \\
\hline \multirow[t]{13}{*}{ Acinetobacter baumanii } & 8 & & & & \\
\hline & 27 & & & & \\
\hline & 82 & & & & \\
\hline & 136 & & & & \\
\hline & 141 & & & & \\
\hline & 145 & & & & \\
\hline & 146 & & & & \\
\hline & 149 & & & & \\
\hline & 150 & & & & \\
\hline & 162 & & & & \\
\hline & 179 & & & & \\
\hline & 203 & & & & \\
\hline & 236 & & & & \\
\hline \multirow[t]{3}{*}{ Citrobacter freundii } & 72 & & & & \\
\hline & 202 & & & & \\
\hline & 252 & & & & \\
\hline Enterobacter cloacae & 87 & & & & \\
\hline \multirow[t]{33}{*}{ Escherichia coli } & 9 & & & & \\
\hline & 25 & & & & \\
\hline & 70 & & & & \\
\hline & 71 & & & & \\
\hline & 74 & & & & \\
\hline & 78 & & & & \\
\hline & 81 & & & & \\
\hline & 94 & & & & \\
\hline & 113 & & & & \\
\hline & 121 & & & & \\
\hline & 122 & & & & \\
\hline & 123 & & & & \\
\hline & 124 & & & & \\
\hline & 135 & & & & \\
\hline & 137 & & & & \\
\hline & 140 & & & & \\
\hline & 174 & & & & \\
\hline & 177 & & & & \\
\hline & 181 & & & & \\
\hline & 183 & & & & \\
\hline & 184 & & & & \\
\hline & 188 & & & & \\
\hline & 192 & & & & \\
\hline & 195 & & & & \\
\hline & 199 & & & & \\
\hline & 204 & & & & \\
\hline & 206 & & & & \\
\hline & 214 & & & & \\
\hline & 219 & & & & \\
\hline & 227 & & & & \\
\hline & 229 & & & & \\
\hline & 231 & & & & \\
\hline & 232 & & & & \\
\hline
\end{tabular}


Table S2 (Continued)

\begin{tabular}{|c|c|c|c|c|c|}
\hline & Isolate number & Gentamicin & Ciprofloxacin & Trimethoprim-sulfamethoxazole & Piperacillin \\
\hline \multirow[t]{4}{*}{ Escherichia coli } & 246 & & & & \\
\hline & 247 & & & & \\
\hline & 249 & & & & \\
\hline & 255 & & & & \\
\hline \multirow[t]{21}{*}{ Klebsiella pneumoniae } & 3 & & & & \\
\hline & 7 & & & & \\
\hline & 12 & & & & \\
\hline & 39 & & & & \\
\hline & 68 & & & & \\
\hline & 75 & & & & \\
\hline & 83 & & & & \\
\hline & 100 & & & & \\
\hline & 114 & & & & \\
\hline & 134 & & & & \\
\hline & 153 & & & & \\
\hline & 157 & & & & \\
\hline & 161 & & & & \\
\hline & 163 & & & & \\
\hline & 165 & & & & \\
\hline & 210 & & & & \\
\hline & 220 & & & & \\
\hline & 223 & & & & \\
\hline & 243 & & & & \\
\hline & 251 & & & & \\
\hline & 254 & & & & \\
\hline Morganella morganii & 224 & & & & \\
\hline \multirow[t]{2}{*}{ Proteus mirabilis } & 96 & & & & \\
\hline & 182 & & & & \\
\hline \multirow[t]{17}{*}{ Pseudomonas aeruginosa } & 11 & & & & \\
\hline & 14 & & & & \\
\hline & 15 & & & & \\
\hline & 28 & & & & \\
\hline & 29 & & & & \\
\hline & 38 & & & & \\
\hline & 58 & & & & \\
\hline & 88 & & & & \\
\hline & 102 & & & & \\
\hline & 107 & & & & \\
\hline & 127 & & & & \\
\hline & 138 & & & & \\
\hline & 158 & & & & \\
\hline & 167 & & & & \\
\hline & 170 & & & & \\
\hline & 198 & & & & \\
\hline & 256 & & & & \\
\hline \multirow[t]{2}{*}{ Serratia marcescens } & 79 & & & & \\
\hline & 143 & & & & \\
\hline \multirow{3}{*}{$\begin{array}{l}\text { Stenotrophomonas } \\
\text { maltophilia }\end{array}$} & 211 & & & & \\
\hline & 240 & & & & \\
\hline & 245 & & & & \\
\hline
\end{tabular}

Notes: Black cells, presence of efflux-mediated resistance; white cells, absence of efflux-mediated resistance. 


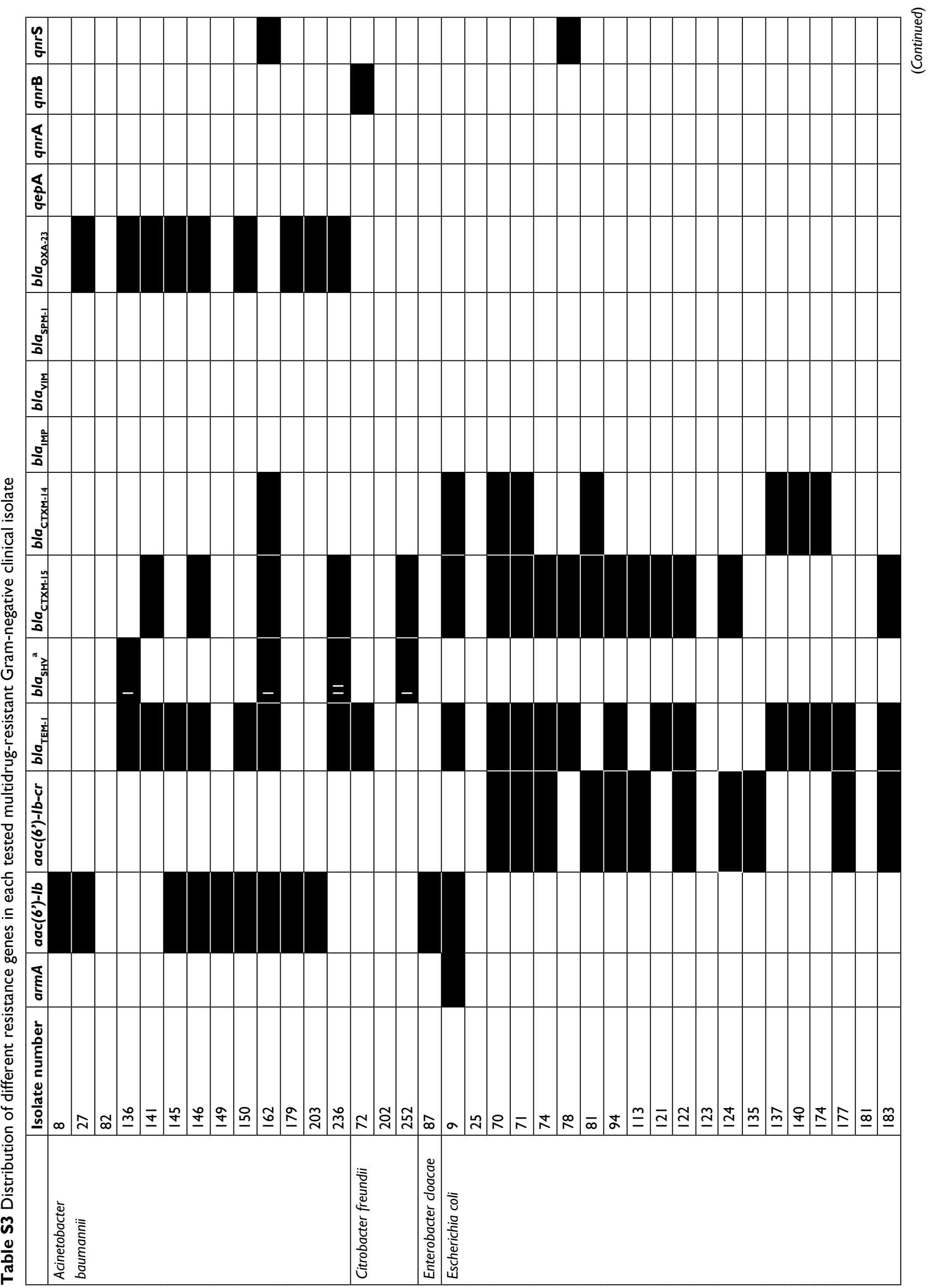




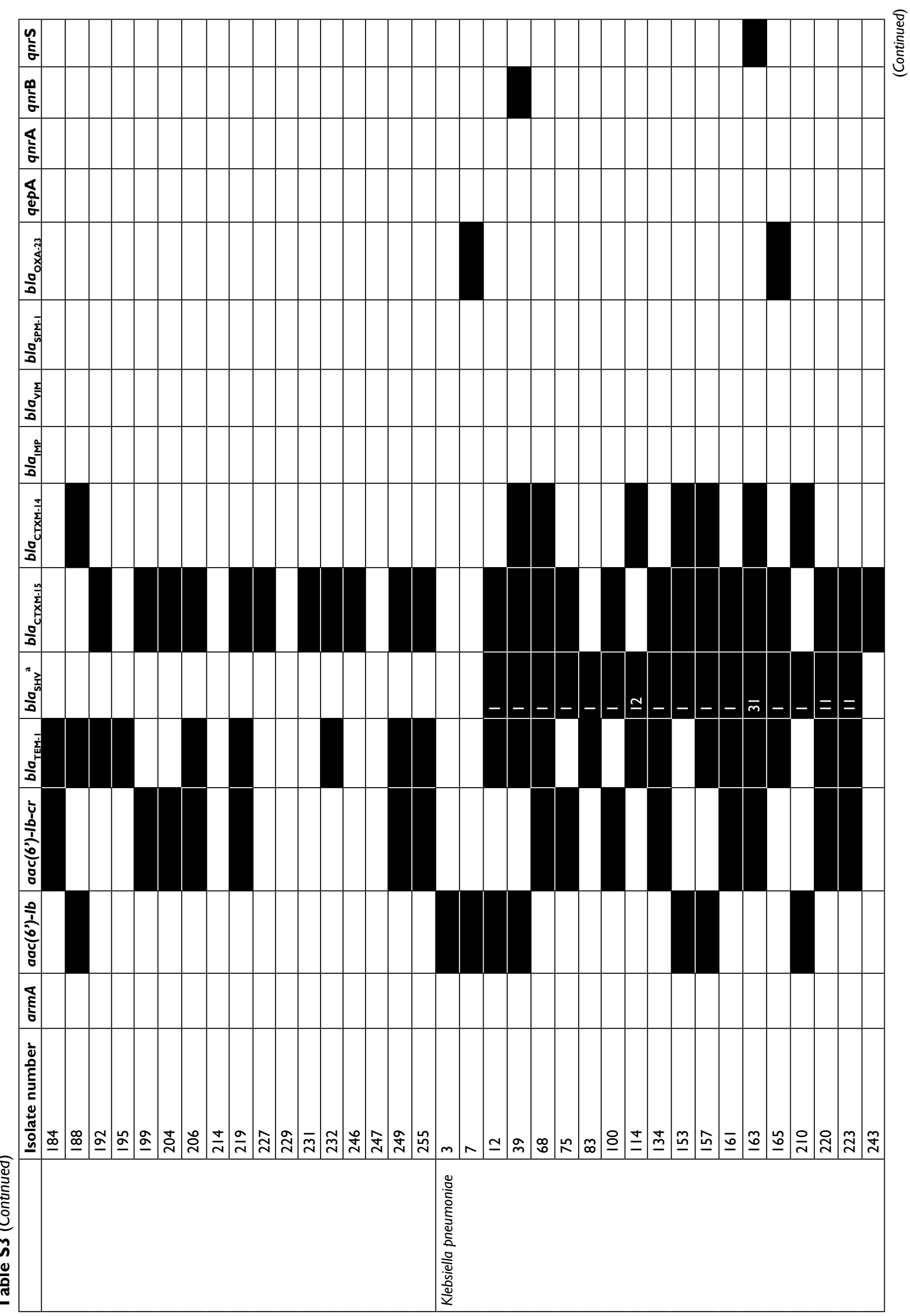




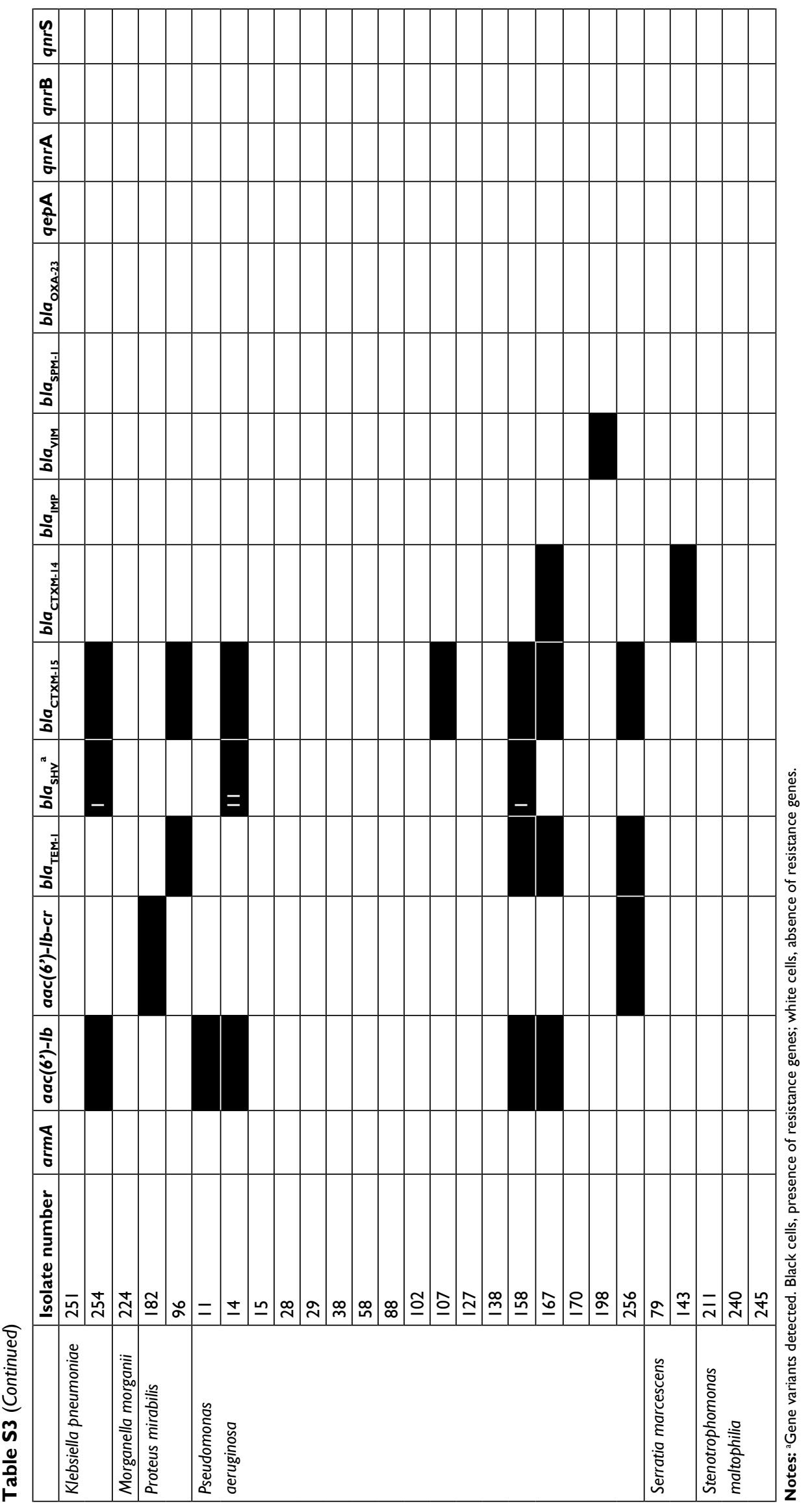



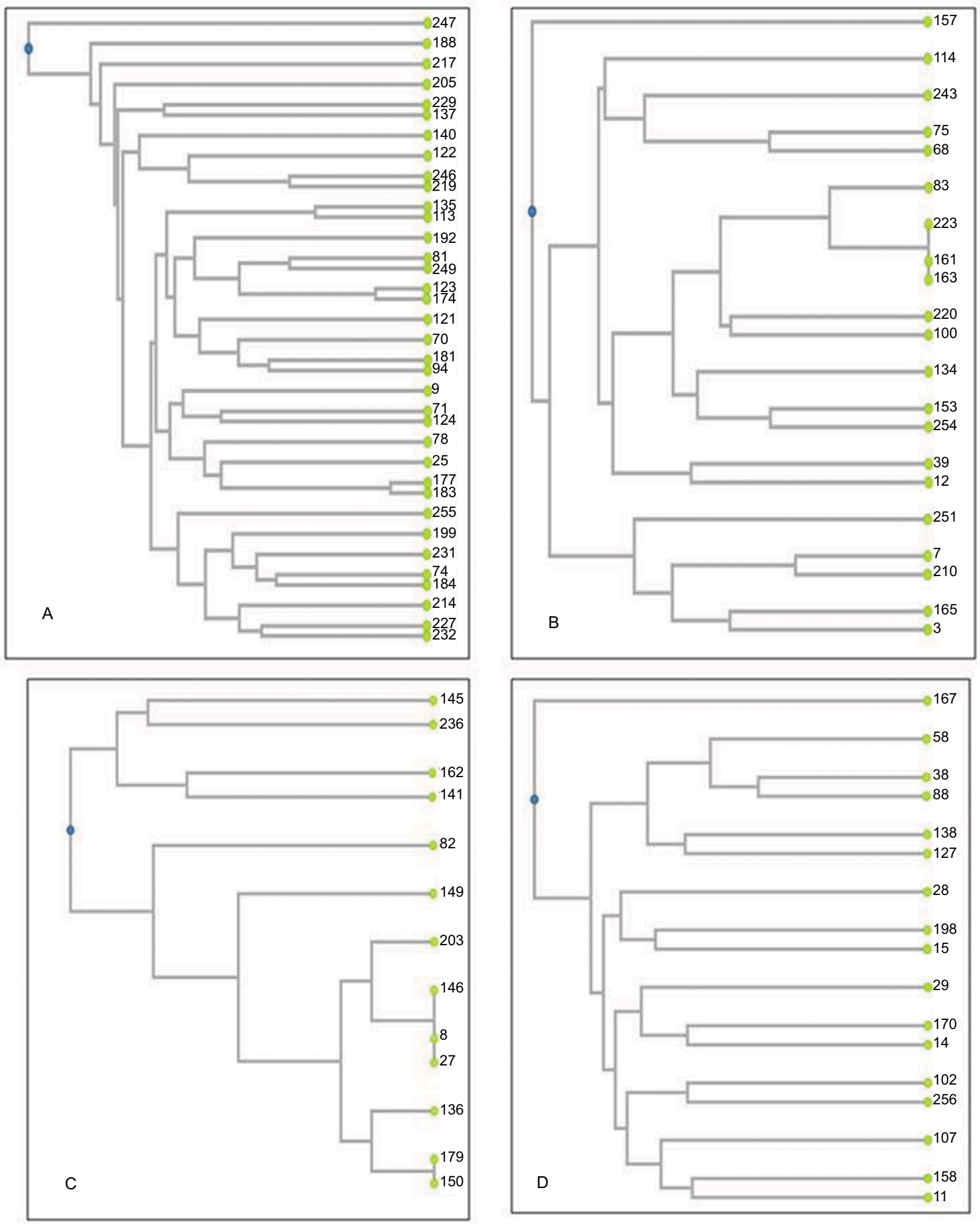

Figure SI Phenogram of different multidrug resistant isolates constructed using UPGMA algorithms based on RAPD analysis.

Notes: (A) Phenogram of Escherichia coli using three different primers; (B) phenogram of Klebsiella pneumoniae using three different primers; (C) phenogram of Acinetobacter baumannii using three different primers; (D) phenogram of Pseudomonas aeruginosa using two different primers.

Abbreviations: RAPD, random amplification of polymorphic DNA; UPGMA, unweighted pair group method with arithmetic mean. 


\section{Publish your work in this journal}

Infection and Drug Resistance is an international, peer-reviewed openaccess journal that focuses on the optimal treatment of infection (bacterial, fungal and viral) and the development and institution of preventive strategies to minimize the development and spread of resistance. The journal is specifically concerned with the epidemiology of antibiotic resistance and the mechanisms of resistance development and diffusion in both hospitals and the community. The manuscript management system is completely online and includes a very quick and fair peerreview system, which is all easy to use. Visit http://www.dovepress.com/ testimonials.php to read real quotes from published authors.

Submit your manuscript here: https://www.dovepress.com/infection-and-drug-resistance-journal 